Research Article

\title{
Standardization of Simplicia and Ethanol Extract of Purun Danau (Lepironia articulata (Retz.) Domin) Rhizome
}

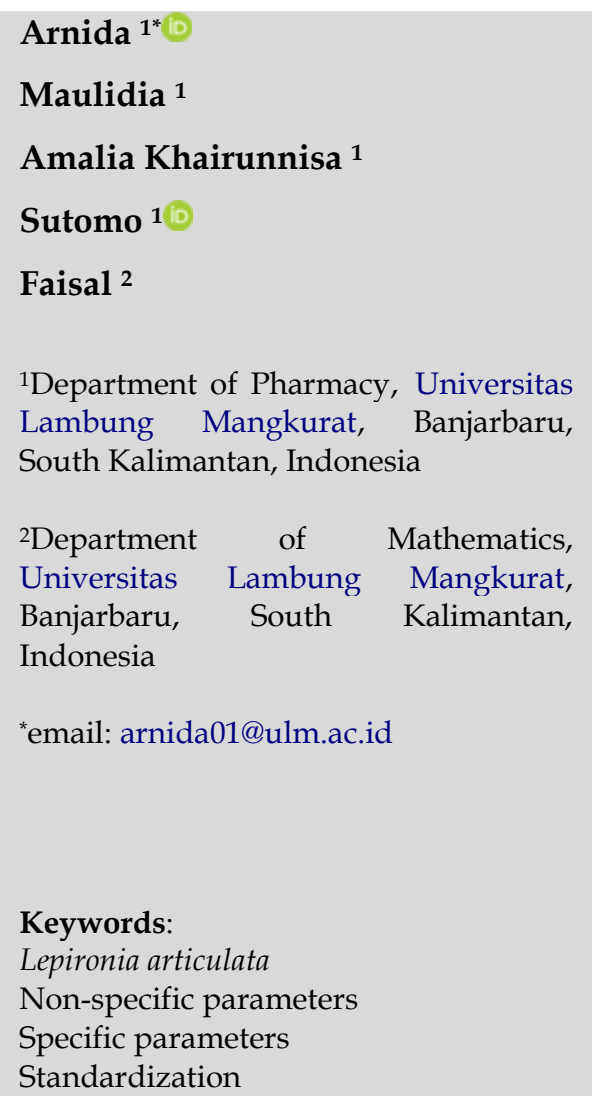

\begin{abstract}
Purun Danau (Lepironia articulata (Retz.) Domin) has been shown to have antimalarial and antioxidant activity. This study aimed to standardize simplicia and extract of L. articulata by determining the value of its specific and non-specific parameters. A sampling of $L$. articulata rhizome was carried out in Guntung Manggis, Haur Gading, and Halat. The standardization method used was based on the Indonesian Herbal Pharmacopoeia and the General Standard Parameter of Extract. The organoleptic observations showed that $L$. articulata simplicia was reddish-brown in color, chelated taste, and had a specific odor. Microscopic observation showed parts of this plant: epidermis, cortex, endodermis, parenchyma, bundle vessels, and scalariform vessels. Ethanol-soluble extract content was 10.00$12.66 \%$, water-soluble extract content $8.03-10.87 \%$, drying shrinkage 7.10-7.33\%, total ash content $2.03-2.52 \%$, acid-insoluble ash $0.33-0.42 \%$, $\mathrm{Pb}$ content 5.698-9.989 ppm, Cd content 0.300-0.500 ppm, Hg content 0.070-0.090 ppm. Ethanol extract of L. articulata rhizome contained alkaloids, flavonoids, tannins, glycosides, and saponins. The yield obtained was $8.05-11.23 \%$, total ash content was $1.58-1.67 \%$, acidinsoluble ash was $0.23-0.33 \%$, and water content was $7.10-8.50 \%$. Standardization of simplicia and ethanol extract of $L$. articulata rhizome has met the criteria.
\end{abstract}

Received: October $6^{\text {th }}, 2021$

Accepted: November 13 $3^{\text {th }}, 2021$

Published: November 30th, 2021

(C) 2021 Arnida, Maulidia, Amalia Khairunnisa, Sutomo, Faisal. Published by Institute for Research and Community Services Universitas Muhammadiyah Palangkaraya. This is an Open Access article under the CC-BYSA License (http://creativecommons.org/licenses/by-sa/4.0/). DOI: https://doi.org/10.33084/bjop.v4i4.2794

\section{INTRODUCTION}

One of the plants known to be efficacious as medicine is purun danau (Lepironia articulata (Retz.) Domin), especially the rhizome. Our previous study showed that the ethanolic extract of the rhizome of L. articulata contained alkaloids, flavonoids, tannins, saponins, and anthraquinone compounds'. The rhizome of L. articulata has antimalarial and antioxidant activity². Traditional medicinal raw materials from plants are often constrained by scientific research in clinical trial research and standardization of these traditional medicinal raw materials ${ }^{3}$.
The L. articulata plant is generally used as raw material for making hands woven by utilizing its stems. The plants are widespread in several countries such as Sri Lanka, India, China, Indonesia, Malaysia, Micronesia, Australia, New Caledonia, and Fijï. The plant can live in a swamp or brackish land, which is included in the Cyperaceae group so that $L$. articulata may contain chemical compounds of alkaloids, flavonoids, steroids, and tannins ${ }^{5}$. The dominant plant part of L. articulata widely studied because it is considered efficacious is the rhizome. Lepironia articulata, emergent aquatic to approximately $200 \mathrm{~cm}$ tall, grow in Esk River, New South Wales, Australia. Lepironia articulata (grey-green plant to 
left-hand side foreground) growing with Machaerina articulata (right-hand side) and naturalized Nymphaea caerulea (mid-foreground). Pseudo-lateral inflorescence at the functionally female stage, past functionally male phase with spider and grey mold and fully mature, with most fruits and bracts fallen 6 .

The development of Indonesian traditional medicines continues to be carried out towards obtaining standardized herbal medicinal products and phytopharmaceuticals, so the raw materials for these medicines must meet the quality standards of materials expected to guarantee their safety and efficacy? ${ }^{7}$. The thing that can be done to meet the quality standards of medicinal raw materials is to standardize the raw materials of the drug. Standardization is a series of procedures or tests carried out physically, chemically, and biologically to ensure the quality of drugs and the quality of raw materials is obtained ${ }^{8}$. This study aims to determine the standardization of simplicia and ethanol extract of L. articulata rhizome consisting of specific and non-specific parameters. Specific parameters include organoleptic, microscopic, ethanol-soluble extract content, water-soluble extract content, description of extracts, yield, and phytochemical screening. Nonspecific parameters include drying shrinkage, total ash content, acid insoluble ash content, and metal contamination.

\section{MATERIALS AND METHODS}

\section{Materials}

The tools used were furnace (Ney-Vulcan D-550), hot plate stirrer (Stuart), atomic absorption spectrophotometer, microscope, oven (Vinco), silica gel plate 254, analytical balance (Pioneer), water bath (SMIC). The materials used in this study were fresh rhizome of $L$. articulata (Retz.) Domin (Figure 1) obtained from three sites in South Kalimantan: Guntung Manggis in the city of Banjarbaru (A), Haur Gading in the Hulu Sungai Tengah Regency (B), and Halat in the Balangan Regency (C), as presented in Figure 2. The determination of this plant was carried out at the Indonesian Institute of Sciences, Bogor, Indonesia, with specimen number B43/IV/DI.01/2021. The reagent used was hydrochloric acid, nitric acid, sulfuric acid, ethanol, ethyl acetate, $\mathrm{FeCl}_{3}$, $10 \%$ gelatin, potassium hydroxide, chloroform, nhexane, sodium hydroxide, methanol, Dragendorff's reagent, Liebermann Burchard's reagent, Mayer's reagent, magnesium powder, and toluene.

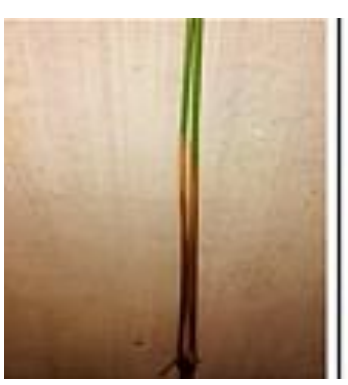

A

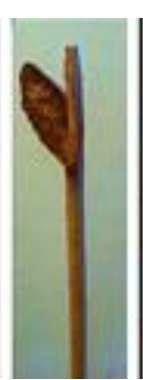

B

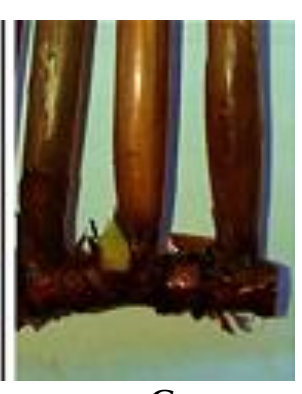

C
Figure 1. Stem (A), flower (B), and rhizome (C) of L. articulata

\section{Methods}

\section{Simplicia preparation}

Lepironia articulata was obtained from swamp area by purposive sampling method. The determination of the three selected locations was based on the consideration of the size of the growing L. articulata population and the condition of the geographical area. The fresh L. articulata rhizomes were sorted and cleaned, and then chopped. The rhizome of $L$. articulata was dried using an oven at a temperature of $55^{\circ} \mathrm{C}$ until the sample was dry with a water content of less than $10 \%$. This temperature range was ideal for drying herbal raw materials, because higher drying temperatures could destroy the active components in simplicia. Furthermore, the simplicia was powdered with a number 25 sieve until a fine powder was obtained9. Lepironia articulata rhizome simplicia obtained weighing about $600 \mathrm{~g}$ from $1000 \mathrm{~g}$ of fresh samples. 


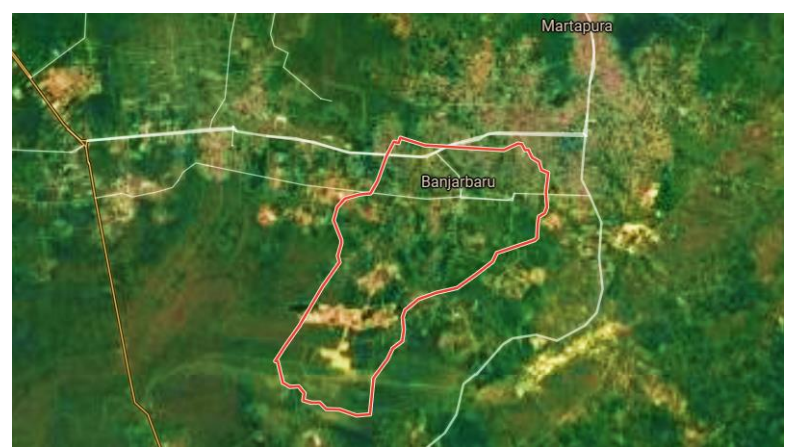

A

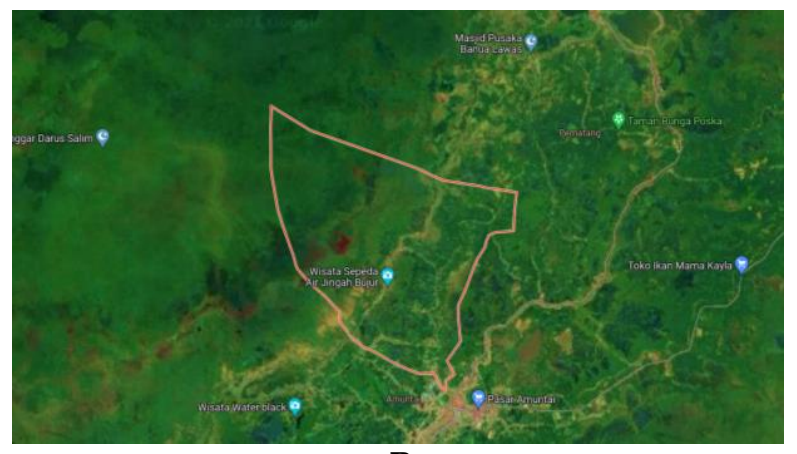

B

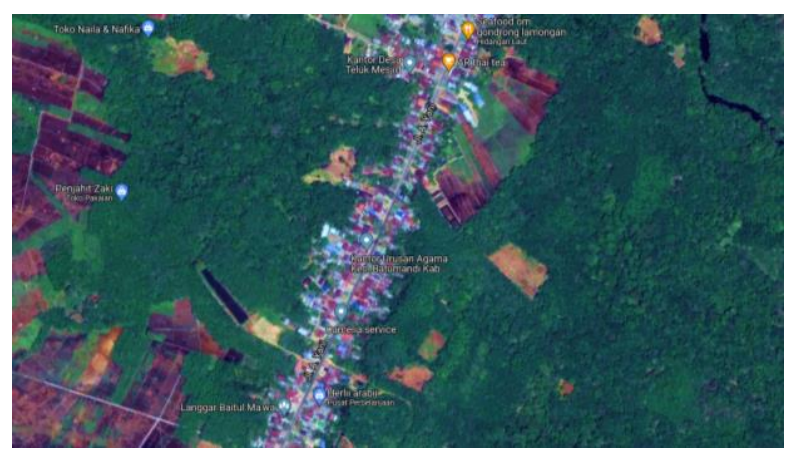

C

Figure 2. Map of sampling areas in Guntung Manggis (A), Haur Gading (B), and Halat (C)

\section{Ethanol extract preparation}

As much as $400 \mathrm{~g}$ of L. articulata simplicia powder was put into the macerator, then $96 \%$ ethanol solvent was added until all simplicia was submerged. The filtering process was carried out for five days, in which every 24 hours, the solvent was changed and continuously stirred every six hours. The filtrate was then evaporated using a water bath until a thick extract was obtained. The method used for solvent evaporation is rotary evaporation. The extract obtained was weighed, and the yield was expressed in percentage $\mathrm{w} / \mathrm{w}^{10,11}$.

\section{Simplicia standardization (Specific parameters)}

1. Organoleptic test

Organoleptic tests were carried out using the five senses to determine the form, color, smell, and taste of the $L$. articulata simplicia. Observations were made after the simplicia came into contact with air for 15 minutes ${ }^{12}$.

2. Microscopic test

Microscopic tests were carried out using a microscope with a magnification of $10 x$, with transverse and longitudinal preparations.

3. Ethanol-soluble extract content

As much as $5 \mathrm{~g}$ of $L$. articulata simplicia powder was macerated with $100 \mathrm{~mL}$ of $96 \%$ ethanol for 18 hours. The $20 \mathrm{~mL}$ filtrate was evaporated until dried in a porcelain dish. The remaining filtrate was heated at $105^{\circ} \mathrm{C}$ until the weight remained constant.

4. Water-soluble extract content

As much as $5 \mathrm{~g}$ of $L$. articulata simplicia powder was macerated with $100 \mathrm{~mL}$ of chloroform saturated distilled water in Erlenmeyer for 18 hours. The $20 \mathrm{~mL}$ filtrate was evaporated to dryness in a porcelain dish. The remaining filtrate was heated at $105^{\circ} \mathrm{C}$ until the weight remained constant.

\section{Simplicia standardization (Non-specific parameters)}

1. Drying shrink

The porcelain crucible was heated at $105^{\circ} \mathrm{C}$ for 30 minutes then added with 1-2 $\mathrm{g}$ of $L$. articulata simplicia. The silicate crucible containing simplicia was left open in the oven at $105^{\circ} \mathrm{C}$ for 30 minutes until the weight remained constant.

2. Total ash content

Simplicia powder $(2 \mathrm{~g})$ in a crucible that had been tared was put at incandescent at $800^{\circ} \mathrm{C}$ for 6 hours, then cooled and weighed. Total ash content was calculated to the initial powder weight in $\% \mathrm{w} / \mathrm{w}$. 


\section{Acid-insoluble ash content}

Five grams of simplicia powder was macerated with $100 \mathrm{~mL}$ of $96 \%$ ethanol for 18 hours. The $20 \mathrm{~mL}$ filtrate was evaporated to dryness in a porcelain dish. The remaining filtrate was heated at $105^{\circ} \mathrm{C}$ until the weight remained constant.

4. Metal contamination of $\mathrm{Pb}, \mathrm{Hg}$, and $\mathrm{Cd}$

Thirty grams of simplicia powder was placed in a porcelain cup then ignited in a furnace. The temperature was gradually increased to $100^{\circ} \mathrm{C}$ every 30 minutes until the temperature reached $450^{\circ} \mathrm{C}$ and allowed to stand until the ash turned white. The ash is then cooled at room temperature. After cooling, 5 $\mathrm{mL}$ of $6 \mathrm{MHCl}$ was added while shaking until the ash dissolved. The solution was evaporated on a hotplate at $100^{\circ} \mathrm{C}$ until dried. The sample was added with 10 $\mathrm{mL}$ of $0.1 \mathrm{M} \mathrm{HNO}_{3}$ and then cooled for an hour. The solution was added $0.1 \mathrm{M} \mathrm{HNO}_{3}$ to $100 \mathrm{~mL}$, then filtered with Whatman paper, and the filtrate was read using an atomic absorption spectrophotometer $(\mathrm{AAS})^{13}$.

\section{Extract standardization (Specific parameters)}

1. Description of extract

The description of the extract used the five senses in terms of describing color, smell, and taste ${ }^{11}$.

2. Yield

The yield was the percentage of the extract obtained from simplicia.

3. Phytochemical screening

Harborne developed the standard procedure to analyze biologically active compounds, including alkaloids, saponins, flavonoids, tannins, anthraquinones, phenolics, glycosides, triterpenoids, and steroids ${ }^{14}$.

a. Alkaloids

As much as $0.2 \mathrm{~g}$ of the thick extract of the rhizome of L. articulata was dissolved in $2 \mathrm{~mL}$ of ethanol and then dripped with $2 \mathrm{~N} \mathrm{HCl}$ then divided into two test tubes of $1 \mathrm{~mL}$ each. In the first tube, ten drops of Mayer's reagent were added, in which a positive result was indicated by the formation of a yellow or white precipitate. In the second tube, ten drops of Dragendorff's reagent were added, in which the presence of an orange precipitate indicated alkaloid's existence ${ }^{15}$.

b. Triterpenoids and steroids

As much as $0.1 \mathrm{~g}$ of the thick extract of the rhizome of L. articulata was dissolved in $1 \mathrm{~mL}$ of ethanol, then ten drops of Liebermann Burchard reagent were added. A color change indicated the positive results, as triterpenoids would appear red-purple while steroids would appear blue-green ${ }^{16}$.

c. Saponins

As much as $0.1 \mathrm{~g}$ of the thick extract of the rhizome of L. articulata was added with $10 \mathrm{~mL}$ of hot water, then two drops of $2 \mathrm{~N} \mathrm{HCl}$ were added. Saponins were indicated by the formation of stable foam as high as $1-10 \mathrm{~cm}$ for not less than 10 minutes ${ }^{17}$.

d. Flavonoids

As much as $0.1 \mathrm{~g}$ of the thick extract of the rhizome of L. articulata was dissolved in $1 \mathrm{~mL}$ of ethanol. The solution was then added with $\mathrm{Mg}$ powder and a drop of concentrated $\mathrm{HCl}$. A change in color to orange, red, or yellow indicated positive results ${ }^{18}$.

e. Tannins

As much as $0.1 \mathrm{~g}$ of the thick extract of the rhizome of L. articulata was dissolved in $1 \mathrm{~mL}$ of ethanol. The test solution was added with $1 \mathrm{~mL}$ of $10 \%$ gelatin. The appearance of a white precipitate indicated positive results ${ }^{19}$.

f. Anthraquinone

As much as $0.1 \mathrm{~g}$ of the thick extract of the rhizome of L. articulata was dissolved in $1 \mathrm{~mL}$ of ethanol, 
then added with ten drops of $10 \% \mathrm{KOH}$ (in methanol). A change in color to yellow or yellowbrown indicated the presence of anthraquinone ${ }^{20}$.

g. Phenolic

As much as $0.1 \mathrm{~g}$ of the thick extract of the rhizome of L. articulata was dissolved in $1 \mathrm{~mL}$ of ethanol, then added with five drops of $10 \% \mathrm{FeCl}_{3}$. A change in color to blue-black indicated phenolics presence ${ }^{21}$.

h. Glycoside

As much as $0.1 \mathrm{~g}$ of the thick extract of the rhizome of L. articulata was dissolved in $1 \mathrm{~mL}$ of ethanol, then added with ten drops of chloroform and concentrated sulfuric acid. A change in color to brown indicated positive results 22 .

Extract standardization (Non-specific parameters)

1. Water content

Measurement of water content was carried out using toluene distillation. Five grams of $L$. articulata thick extract was placed in a round bottom flask and then added toluene solvent that had been saturated with $200 \mathrm{~mL}$ of water. The solution was heated for 100 minutes until the toluene boiled. After it was boiled, then the solution was cooled to room temperature. The volume of water was read after the toluene and water had separated. The water content was determined in percentage.

2. Total ash content

Two grams of thick extract in a crucible ignited at $800^{\circ} \mathrm{C}$ for six hours, then cooled and weighed. Total ash content was calculated to the initial powder weight in $\% \mathrm{w} / \mathrm{w}$.

3. Acid-insoluble ash content

The ash obtained from the total ash content test was boiled with $25 \mathrm{~mL}$ of dilute $\mathrm{HCl}$ for five minutes. The ash was then filtered using ash-free filter paper and then washed with hot water to collect acid-insoluble ash, then ignited with a porcelain crucible in a furnace to obtain ash with a constant weight. The content was calculated from the initial weight of the powder, expressed in $\% \mathrm{w} / \mathrm{w}^{23}$.

\section{Data Analysis}

The results obtained showed in qualitative and quantitative data. Qualitative data were the results of organoleptic, microscopic, and phytochemical screening. In contrast, quantitative data resulted from drying shrinkage testing, water content, total ash content, acidinsoluble ash content, water-soluble extract content, ethanol-soluble extract content, and heavy metal contamination levels. The data was made in tabular form along with the documentation and analyzed descriptively.

\section{RESULTS AND DISCUSSION}

\section{Ethanol extract preparation}

The results obtained from each growing place were different, as presented in Table I. This result was more than our previous study, in which from $400 \mathrm{~g}$ of $L$. articulata rhizome powder using the maceration method for $3 \times 24$ hours and the solvent used was $96 \%$ ethanol, the yield was $8.232 \%^{1}$. Sampling was carried out in three different places with different environmental factors that affected the yield. Metabolism in plants is influenced by environmental factors such as soil, altitude, light, temperature, humidity, organic compounds, and inorganic compounds. Specimens of the same plant species grown under different environmental conditions showed significant differences in the production and accumulation of primary and secondary metabolites. Chemical interactions between plants and their environment are mediated primarily by the biosynthesis of secondary metabolites, which carry out their biological roles, as a plastic adaptive response to their environment ${ }^{24}$. 
Table I. Yield of L. articulata rhizome ethanol extract

\begin{tabular}{lccc}
\hline \multicolumn{1}{c}{ Area } & $\begin{array}{c}\text { Powder } \\
\text { weight }(\mathrm{g})\end{array}$ & $\begin{array}{c}\text { Thick extract } \\
\text { weight }(\mathrm{g})\end{array}$ & Yield (\%) \\
\hline $\begin{array}{l}\text { Guntung } \\
\text { Manggis }\end{array}$ & 400 & 44.90 & 11.23 \\
$\begin{array}{l}\text { Haur } \\
\text { Gading }\end{array}$ & 400 & 37.81 & 9.45 \\
Halat & 400 & 32.18 & 8.05 \\
\hline
\end{tabular}

\section{Simplicia standardization (Specific parameters)}

Organoleptic test

The organoleptic test was carried out with the help of five panelists who explained the shape, color, smell, and taste of the simplicia, as presented in Table II. Lepironia articulata simplicia powder has a characteristic odor, with a chelate taste and reddish-brown color. The simplicia of L. articulata had a chelate taste with a reddish-brown color because it contains tannins and polyphenols ${ }^{25}$.

Table II. Organoleptic properties of L. articulata simplicia

\begin{tabular}{|c|c|c|c|c|}
\hline Area & Smell & Taste & Color & Form \\
\hline $\begin{array}{l}\text { Guntung } \\
\text { Manggis }\end{array}$ & Specific & Chelate & $\begin{array}{l}\text { Reddish- } \\
\text { brown }\end{array}$ & $\begin{array}{l}\text { Coarse } \\
\text { powder }\end{array}$ \\
\hline $\begin{array}{l}\text { Haur } \\
\text { Gading }\end{array}$ & Specific & Chelate & $\begin{array}{l}\text { Reddish- } \\
\text { brown }\end{array}$ & $\begin{array}{l}\text { Coarse } \\
\text { powder }\end{array}$ \\
\hline Halat & Specific & Chelate & $\begin{array}{l}\text { Reddish- } \\
\text { brown }\end{array}$ & $\begin{array}{l}\text { Coarse } \\
\text { powder }\end{array}$ \\
\hline
\end{tabular}

\section{Microscopic test}

Microscopic tests were carried out using an optical microscope with a magnification of 10 times to observe the constituent elements of a sample. Microscopic observations on the rhizome of $L$. articulata were carried out transversely (cross) and longitudinally. The results of cross-sections of L. articulata rhizomes from the three locations showed the same results covering the epidermis, cortex, endodermis, cortical parenchyma, and bundle vessels (Figure 3). The cross section of $L$. articulata rhizome from the three locations also showed similar results, consisting of parenchyma cells and scaliform vessels (Figure 4), which results were also found in longitudinal sections.

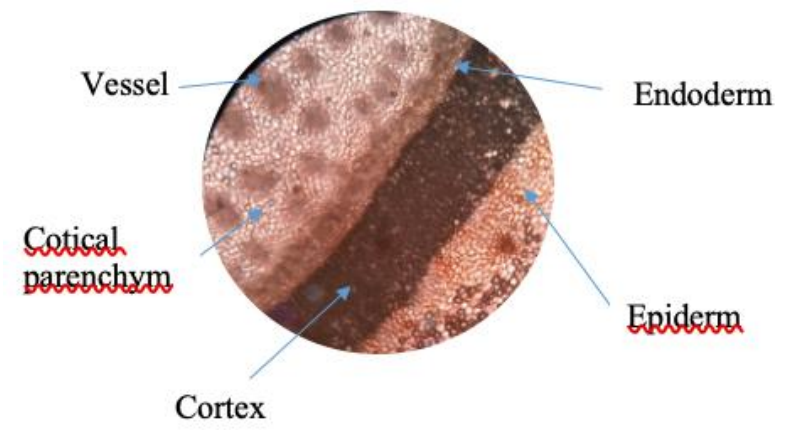

Figure 3. Cross section of L. articulata rhizome

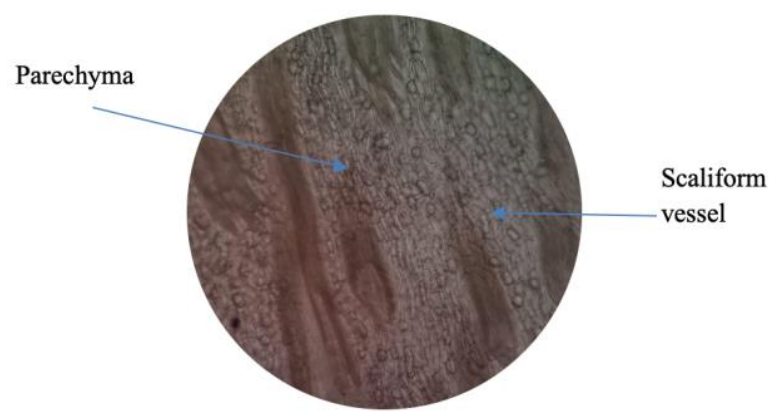

Figure 4. Longitudinal section of L. articulata rhizome

Ethanol and water-soluble extract content

The results obtained in determining the levels of dissolved compounds are relatively small, as presented in Table III. The results were different because the samples used in this study were taken from three different places. Differences in plant growth area affect the percentage composition of chemical compounds in a plant ${ }^{26}$. The water solvent used aims to dissolve polar compounds, and ethanol solvent is used to dissolve polar-nonpolar compounds ${ }^{27}$.

Table III. Determination of water-soluble and ethanolsoluble extract content of L. articulata simplicia

\begin{tabular}{lcc}
\hline \multicolumn{1}{c}{ Area } & $\begin{array}{c}\text { Water-soluble } \\
\text { extract content (\%) }\end{array}$ & $\begin{array}{c}\text { Ethanol-soluble } \\
\text { extract content (\%) }\end{array}$ \\
\hline $\begin{array}{l}\text { Guntung } \\
\text { Manggis }\end{array}$ & $10.87 \pm 0.15$ & $12.66 \pm 0.05$ \\
$\begin{array}{l}\text { Haur } \\
\text { Gading }\end{array}$ & $8.80 \pm 0.10$ & $10.73 \pm 0.15$ \\
Halat & $8.03 \pm 0.15$ & $10.00 \pm 0.10$ \\
\hline
\end{tabular}

\section{Simplicia standardization (Non-specific parameters)}

The results of non-specific parameter testing of $L$. articulata rhizome simplicia were presented in Table IV. The results of the drying shrinkage test of L. articulata 
rhizome simplicia meet the standards set by the Food and Drug Supervisory Agency of the Republic of Indonesia (BPOM RI), which is less than $10 \%{ }^{28}$. Dry shrinkage is generally related to the water content contained in simplicia, so the smaller the drying loss, the better the results obtained. The smaller the water content contained in simplicia, it can reduce the growth of molds and fungi as well as enzymatic reactions that can damage the quality of simplicia29.

Data on total ash content and acid-insoluble ash content in the simplicia rhizome of L. articulata did not differ. The higher the total ash content obtained, the higher the mineral content contained in the simplicia. Humans need minerals such as calcium, phosphorus, and magnesium for bone formation, sodium, and chloride for body fluids, and iron to form hemoglobin and red blood cells. Minerals can also be harmful if they accumulate in the human body over a long time, which can interfere with the circulatory, nervous, and kidney systems such as mercury, lead, copper, cadmium, and strontium ${ }^{30}$. The acid-insoluble ash content reflects the contamination of minerals or metals that are not acid soluble in the simplicia. The high content of acid-insoluble ash in simplicia indicates the presence of impurities such as soil or sand, metallic elements silver, lead, and mercury ${ }^{15,23}$. Measurement of metal content ensures that the samples do not contain heavy metals that can endanger health if they exceed the specified requirements ${ }^{12}$. Based on the results obtained, the $\mathrm{Cd}$ levels from the three sites did not meet the specified requirements ${ }^{31}$. The results obtained can be influenced by genetic factors and environmental factors. The simplicia processing process can also cause high levels of cadmium metal from sampling to sample processing, such as in the sample washing process, which may be less clean because the sample used itself is a rhizome so that the risk factor is greater. The use of metal materials during sample processing can affect the results obtained-in the sample processing, chopping the rhizome using a machete made of iron so that metal contamination is possible. Therefore, it can be reviewed more carefully in terms of simplicia processing.

Table IV. Non-specific parameter testing of L. articulata simplicia

\begin{tabular}{|c|c|c|c|c|}
\hline \multirow{2}{*}{ 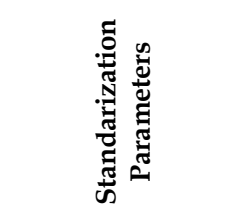 } & \multicolumn{3}{|c|}{ Result } & \multirow{2}{*}{ } \\
\hline & 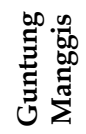 & 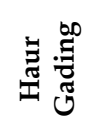 & $\frac{\hbar}{\frac{\pi}{\pi}}$ & \\
\hline $\begin{array}{l}\text { Drying shrinkage } \\
(\%)\end{array}$ & 7.78 & 7.10 & 7.33 & $<10$ \\
\hline $\begin{array}{l}\text { Total ash content } \\
(\%)\end{array}$ & 2.52 & 2.03 & 2.05 & - \\
\hline $\begin{array}{l}\text { Acid-insoluble ash } \\
\text { content }(\%)\end{array}$ & 0.43 & 0.33 & 0.42 & - \\
\hline $\begin{array}{l}\mathrm{Pb} \text { contamination } \\
(\mathrm{mg} / \mathrm{kg})\end{array}$ & 9.989 & 5.698 & 6.297 & $\leq 10$ \\
\hline $\begin{array}{l}\text { Cd contamination } \\
(\mathrm{mg} / \mathrm{kg})\end{array}$ & 0.499 & 0.500 & 0.300 & $\leq 0.03$ \\
\hline $\begin{array}{l}\mathrm{Hg} \text { contamination } \\
(\mathrm{mg} / \mathrm{kg})\end{array}$ & 0.070 & 0.079 & 0.090 & $\leq 0.5$ \\
\hline
\end{tabular}

\section{Extract standardization (Specific parameters)}

\section{Description of extract}

Extract description is the initial stage in the introduction, which is carried out as simply and objectively as possible by using the five senses with the help of panelists who are asked to describe the shape, color, smell, and taste of the L. articulata rhizome extract, as presented in Table $\mathbf{V}$. Based on the results presented by the panelists, the ethanolic extracts of L. articulata rhizomes in three places all had a thick extract form, a characteristic odor, and a chelating taste. The data obtained from the panelists are collected and converted into quantitative data (quantification) using 'coding' so that conclusions can be drawn from the organoleptic results. Towaha reported that the taste of chelates in plants is because it contains tannins and polyphenol compounds ${ }^{32}$. The smell of the $L$. articulata rhizome ethanol extract from the three places obtained a distinctive and more pungent odor than simplicia because the compounds contained in the $L$. articulata rhizome had been extracted. The color of the $L$. articulata rhizome ethanol extract from the three places 
was reddish-brown which was more concentrated than the liquid extract due to the concentration process.

Table V. Organoleptic examination of L. articulata etanol extract

\begin{tabular}{|c|c|c|c|c|c|}
\hline \multirow{2}{*}{ Area } & \multicolumn{4}{|c|}{ Parameters } & \multirow{2}{*}{$\begin{array}{l}\text { Extract } \\
\text { profile }\end{array}$} \\
\hline & Form & Color & Smell & Taste & \\
\hline $\begin{array}{l}\text { Guntung } \\
\text { Manggis }\end{array}$ & $\begin{array}{l}\text { Thick } \\
\text { Extract }\end{array}$ & $\begin{array}{l}\text { Reddish- } \\
\text { brown }\end{array}$ & Specific & Chelate & \\
\hline $\begin{array}{l}\text { Haur } \\
\text { Gading }\end{array}$ & $\begin{array}{l}\text { Thick } \\
\text { Extract }\end{array}$ & $\begin{array}{l}\text { Reddish- } \\
\text { brown }\end{array}$ & Specific & Chelate & \\
\hline Halat & $\begin{array}{l}\text { Thick } \\
\text { Extract }\end{array}$ & $\begin{array}{l}\text { Reddish- } \\
\text { brown }\end{array}$ & Specific & Chelate & \\
\hline
\end{tabular}

\section{Phytochemical screening}

Screening of phytochemical content of ethanolic extract of L. articulata rhizome aims to determine the content of active ingredients, which are secondary metabolites in plants. These active ingredients can function as a plant's self-defense against the environment, disease, and insects ${ }^{33}$. The results of phytochemical screening of $L$. articulata rhizome extract at three locations indicated the presence of alkaloids, flavonoids, saponins, anthraquinones, glycosides, tannins, and phenolics, as presented in Table VI. This is consistent with our previous study, which also reported the presence of alkaloids, flavonoids, tannins, saponins, and anthraquinones ${ }^{1}$.

Table VI. Phytochemical screening of L. articulata etanol extract

\begin{tabular}{|c|c|c|c|}
\hline Phytochemicals & $\begin{array}{l}\text { Guntung } \\
\text { Manggis }\end{array}$ & $\begin{array}{c}\text { Haur } \\
\text { Gading }\end{array}$ & Halat \\
\hline Alkaloids & + & + & + \\
\hline Terpenoids/steroids & - & - & - \\
\hline Flavanoids & + & + & + \\
\hline Saponins & + & + & + \\
\hline Anthraquinones & + & + & + \\
\hline Glycosides & + & + & + \\
\hline Tannins & + & + & + \\
\hline Phenolics & + & + & + \\
\hline
\end{tabular}

\section{Extract standardization (Non-specific parameters)}

The results of non-specific parameter testing of $L$. articulata rhizome ethanol extract included water content, total ash content, and acid-insoluble ash content, as presented in Table VII. The total ash content and acidinsoluble ash obtained from the three sites did not show a significant difference. This value has met the requirements set by BPOM RI, which states that the water content contained in the extract should not be more than $10 \%$.

Table VII. Non-specific parameter testing of L. articulata etanol extract

\begin{tabular}{|c|c|c|c|c|}
\hline \multirow{2}{*}{ 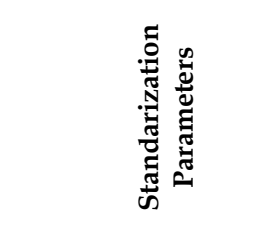 } & \multicolumn{3}{|c|}{ Results } & \multirow{2}{*}{ 苞 } \\
\hline & 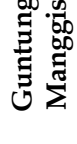 & 艼 & $\frac{\pi}{\pi}$ & \\
\hline Water content (\%) & 8.50 & 7.10 & 7.60 & $\leq 10$ \\
\hline Total ash content (\%) & 1.67 & 1.58 & 1.63 & - \\
\hline $\begin{array}{l}\text { Acid-insoluble ash } \\
\text { content }(\%)\end{array}$ & 0.33 & 0.22 & 0.23 & - \\
\hline
\end{tabular}

\section{CONCLUSION}

The results of specific and non-specific parameters of simplicia and ethanol extract of L. articulata rhizome at three different places (Guntung Manggis, Haur Gading, and Halat) can be used as a standard for using L. articulata rhizome as raw material for traditional medicine.

\section{ACKNOWLEDGMENT}

The authors would like to express our special thanks of gratitude to Universitas Lambung Mangkurat Research and Community Service Institute (LPPM) for research funding in the ULM PNBP PWDM program with grant number: 697/UN8/PG/2021 March 22, 2021.

\section{AUTHORS' CONTRIBUTION}

Arnida: conceived and design the analysis, writing of the paper. Maulidia: conceived and design the analysis. Amalia Khairunnisa: collected data, contributed data or 
analysis tools. Sutomo: conceived and design the analysis, writing of the paper. Faisal: collected data, contributed data or analysis tools.

\section{DATA AVAILABILITY}

None.

\section{CONFLICT OF INTEREST}

The author declares that there is no conflict of interest.

The author is fully responsible for the content and writing of this article.

\section{REFERENCES}

1. Arnida, Bittaqwa EA, Rahmatika D, Sutomo. Identifikasi Kandungan Senyawa Ekstrak Etanol Rimpang Purun Danau (Lepironia articulata (Retz.) Domin). In: Prosiding Seminar Nasional Lingkungan Lahan Basah 2021. 2021; Banjarmasin, South Kalimantan: Lembaga Penelitian dan Pengabdian kepada Masyarakat Universitas Lambung Mangkurat; 2021. p. 1-6.

2. Kumar SJU, Chaitanya KMJ, Semotiuk AJ, Khrisna V. Indigenous knowledge on medicinal plants used by ethnic communities of South India. Ethnobot Res Appl. 2019;18(4):1-112. doi:10.32859/era.18.4.1-112

3. Salmerón-Manzano E, Garrido-Cardenas JA, Manzano-Agugliaro F. Worldwide Research Trends on Medicinal Plants. Int J Environ Res Public Health. 2020;17(10):3376. doi:10.3390/ijerph17103376

4. Domyos $\mathrm{P}, \mathrm{Te}$-Chato $\mathrm{S}$. In vitro propagation of Lepironia articulata in Kuan Kreng peat lands, Nakhon Si Thammrat. Int J Agric Tech. 2013;9(6):1595-605.

5. Widhoyo H, Kurdiansyah, Yuniarti. Uji fitokimia pada tumbuhan purun danau (Lepironia articulata). J Sylva Scienteae. 2019;2(3):484-92. doi:10.20527/jss.v2i3.1828

6. Prychid CJ, BruhlJJ. Floral ontogeny and gene protein localization rules out euanthial interpretation of reproductive units in Lepironia (Cyperaceae, Mapanioideae, Chrysitricheae). Ann Bot. 2013;112(1):161-77. doi:10.1093/aob/mct111
7. Sutomo, Hasanah N, Arnida, Sriyono A. Standardisasi simplisia dan ekstrak daun matoa (Pometia pinnata J.R Forst \& G. Forst) asal kalimantan selatan. J Pharmascience. 2021;8(1):101-10. doi:10.20527/jps.v8i1.10275

8. Balekundri A, Mannur V. Quality control of the traditional herbs and herbal products: a review. Futur J Pharm Sci. 2020;6:67. doi:10.1186/s43094-020-000915

9. Arnida, Sutomo, Humairah SZA, Fadlilahturrahmah. Heme Polymerization Inhibitory Activity and Phytochemical Screening of Ethyl Acetate Fraction in Manuran (Coptosapelta tomentosa Valeton ex K. Heyne) Stem. J Jamu Indones. 2021;6(1):1-7.

10. Erickson MD, Giguere MT, Whitaker DA. Comparison of Common Solvent Evaporation Techniques in Organic Analysis. Anal Lett. 1981;14(11):841-57. doi:10.1080/00032718108081439

11. Kementerian Kesehatan Republik Indonesia. Farmakope Herbal Indonesia Edisi III. Jakarta, Indonesia: Kementerian Kesehatan Republik Indonesia; 2017.

12. Kementerian Kesehatan Republik Indonesia. Parameter Standar Umum Ekstrak Tumbuhan Obat. Jakarta, Indonesia: Kementerian Kesehatan Republik Indonesia; 2000.

13. Badan Standarisasi Nasional Republik Indonesia. Penentuan kadar logam berat timbal $(\mathrm{Pb})$ dan cadmium (Cd) pada produk Perikanan. SNI 2354.5:2011. Jakarta, Indonesia: Badan Standarisasi Nasional Republik Indonesia; 2011.

14. Harborne JB. Phytochemical Methods: A guide to modern techniques of plant analysis. Dordrecht, Netherlands: Springer; 1984. doi:10.1007/978-94-0095570-7

15. Vernanda RY, Puspitasari MR, Satya HN. Standarisasi Spesifik dan Non Spesifik Simplisia dan Ekstrak Etanol Bawang Putih Tunggal Terfermentasi (Allium sativum Linn.). J Farmasi Sains Terapan. 2019;6(2):74-83. doi:10.33508/jfst.v6i2.2234

16. Sutomo, Fahriah, Arnida. Skrining fitokimia dan uji aktivitas antibakteri ekstrak etanol daun racun ayam (Brucea javanica [L.] Merr.) asal kalimantan selatan. J Ilmiah Ibnu Sina. 2021;6(1):59-68. doi:10.36387/jiis.v6i1.607 
17. Trase GE, Evans WC. Pharmacognosy $13^{\text {th }}$ Edition. London, UK: Baillière Tindall. p. 176-80.

18. Yamin Y, Ruslin R, Sabarudin S, Sida N, Kasmawati H, Diman LOM. Determination of Antiradical Activity, Total Phenolic, and Total Flavonoid Contents of Extracts and Fractions of Langsat (Lansium domesticum Coor.) Seeds. Borneo J Pharm. 2020;3(4):249-56. doi:10.33084/bjop.v3i4.1500

19. Mughrbi HN, Auzi AA, Maghrbi H. Phytochemicals, Nutritional Value, Antioxidant, and Anticoagulant Activity of Lactuca sativa L. Leaves and Stems. Borneo J Pharm. 2020;3(3):152-61. doi:10.33084/bjop.v3i3.1394

20. Jacquemin D, Preat J, Charlot M, Wathelet V, André JM, Perpète EA. Theoretical investigation of substituted anthraquinone dyes. J Chem Phys. 2004;121(4):1736-43. doi:10.1063/1.1764497

21. Tsao R. Chemistry and biochemistry of dietary polyphenols. Nutrients. 2010;2(12):1231-46. doi:10.3390/nu2121231

22. Yadav RNS, Agarwala M. Phytochemical analysis of some medicinal plants. J Phytol. 2011;3(12):10-4.

23. Sutomo, Lestari HD, Arnida, Sriyono A. Simplicia and Extracts Standardization from Jualing Leaves (Micromelum minutum Wight \& Arn.) from South Kalimantan. Borneo J Pharm. 2019;2(2):55-62. doi:10.33084/bjop.v2i2.898

24. Yang L, Wen KS, Ruan X, Zhao YX, Wei F, Wang Q. Response of Plant Secondary Metabolites to Environmental Factors. Molecules. 2018;23(4):762. doi:10.3390/molecules23040762

25. MarlianaSD, Suryanti V, Suyono. The phytochemical screenings and thin layer chromatography analysis of chemical compounds in ethanol extract of labu siam fruit (Sechium edule Jacq. Swartz.). Asian J Nat Prod Biochem. 2005;3(1):26-31. doi:10.13057/biofar/f030106

26. Zhang QW, Lin LG, Ye WC. Techniques for extraction and isolation of natural products: a comprehensive review. Chin Med. 2018;13:20. doi:10.1186/s13020-018-0177-x

27. Abubakar AR, Haque M. Preparation of Medicinal Plants: Basic Extraction and Fractionation Procedures for Experimental Purposes. J Pharm Bioallied Sci. 2020;12(1):1-10. doi:10.4103/jpbs.JPBS_175_19
28. Badan Pengawas Obat dan Makanan Republik Indonesia. Peraturan Badan Pengawas Obat dan Makanan Nomor 32 Tahun 2019 tentang Persyaratan Keamanan dan Mutu Obat Tradisional. Jakarta, Indonesia: Badan Pengawas Obat dan Makanan Republik Indonesia; 2019.

29. Putranti W, Dewi NA, Widyastuti L. Standardization of extract and characterization of emulgel formula of lengkuas (Alpinia galanga (L.) Willd) rhizome extract. J Farm Sains Komun. 2018;15(2):81-91. doi:10.24071/jpsc.001612

30. Jaishankar M, Tseten T, Anbalagan N, Mathew BB, Beeregowda KM. Toxicity, mechanism and health effects of some heavy metals. Interdiscip Toxicol. 2014;7(2):60-72. doi:10.2478/intox-2014-0009

31. Pavarini DP, Pavarini SP, Niehues M, Lopes NP. Exogenous influences on plant secondary metabolite levels. Anim Feed Sci Technol. 2012;176(1-4):5-16. doi:10.1016/j.anifeedsci.2012.07.002

32. Towaha J. Kandungan Senyawa Polifenol pada Biji Kakao dan Kontribusinya terhadap Kesehatan. Sirinov. 2014;2(1):1-16.

33. Kennedy DO, Wightman EL. Herbal Extracts and Phytochemicals: PlantSecondary Metabolites and the Enhancement of Human Brain Function. Adv Nutr. 2011;2(1):32-50. doi:10.3945/an.110.000117 